\title{
Characteristics of Children with Urticaria in the Pediatric Allergy Department
}

\author{
Çocuk Allerji Bölümünde İzlenen Ürtikerli Hastaların Özellikleri
}

Emine DiBEK MISIRLIOĞLU, Serap ÖZMEN, Hilal SUSAM, Önder DOKSÖZ, Mahmut DOĞRU, Handan DUMAN, IIlknur BOSTANCI

Dr. Sami Ulus Woman's and Children's Health Education and Research Hospital, Department of Pediatric Allergy and Asthma,

Ankara, Turkey

\begin{abstract}
Objective: Urticaria is a common condition in children. The causative agent for urticaria cannot be found in the majority of cases. In this study we aimed to investigate the clinical characteristics of the patients diagnosed as urticaria in our outpatient allergy clinic.

Material and Methods: We reviewed the medical records of children with a diagnosis code of urticaria who were followed up in our allergy outpatient clinic between September $1^{\text {st }} 2008$ and August, 31 2009.

Results: Two hundred fifty-eight patients were enrolled, of whom 159 (61.2\%) were male. The patients ranged from 6 months to 17 years old (mean $6.43 \pm 3.97$, median 6 years)with 173 (67\%) diagnosed as acute urticaria, 49 (19\%) as episodic urticaria and 36 (14\%) as chronic urticaria. Physical urticaria was seen in five cases (two as cholinergic, three as cold urticaria). Angioedema accompanied the urticaria in 31 (12\%) cases. Skin biopsies were performed for five patients with characteristics of vasculitic urticaria and biopsy findings of three patients were consistent with vasculitic changes. Infections were the most common etiologic factors and were seen in 122 patients (47\%). Ten (3.9\%) of the patients had food allergy and 6 (2.3\%) had drug allergy. Two patients with chronic urticaria had thyroid autoantibody positivity although they were confirmed as being euthyroid according to blood thyroid hormone levels.
\end{abstract}

Conclusion: Our results show that the most common type of urticaria is the acute type and the most common etiological factor is infection in children.

Key Words: Atopy, Allergy, Children, Infection, Urticaria

\section{ÖZET}

Giriş ve Amaç: Ürtiker çocukluk çağında sık görülmektedir. Hastaların çoğunda nedeni bulunamamaktadır. Çalışmanın amacı çocuk allerji polikliniğinde ürtiker tanısı ile izlenen hastaların klinik özelliklerin belirlenmesidir.

Gereç ve Yöntemler: 1 Eylül 2008-31 Ağustos 2009 tarihleri arasında allerji polikliniğinde ürtiker tanısı alan hastaların kayıtları değerlendirildi.

Bulgular: Yüz elli dokuzu (\%61.2) erkek, toplam 258 hasta değerlendirildi. Hastaların yaşları 6 ay ile 17 yıl (ortalama 6,43 \pm 3,97, ortanca 6 yıl) arasında değişmekteydi. Hastaların 173'ü (\%67) akut ürtiker, 49'u (\%19) tekrarlayan ürtiker ve 36 'sı (\%14) kronik ürtiker tanısı almıştı.

Fiziksel ürtiker 5 hastada (iki kolinerjik, üç soğuk ürtiker) vardı. 31 (\%12) hastada anjioödem eşlik ediyordu. Vaskülit özellik gösteren döküntüleri olan beş hastaya cilt biyopsisi yapılmış ve üçünde vaskülitik değişiklikler saptanmıştı. Enfeksiyonlar en sık görülen etiyolojik faktör olup hastaların 122'sinde (\%47) saptandı. 10 (\%3.9) hastada besin allerjisi ve 6 (\%2.3) hastada ilaç allerjisi vardı. Kronik ürtikerli iki hastanın tiroid antikorları pozitif olup tiroid hormon düzeyleri normaldi.

Sonuç: Çocuklarda en sık görülen ürtiker tipi akut olup enfeksiyonlar ilk sırada yer alan etiyolojik faktördür.

Anahtar Sözcükler: Atopi, Allerji, Çocuk, Enfeksiyon, Ürtiker 


\section{INTRODUCTION}

Urticaria is considered a heterogeneous group of diseases that consists of erythematous, pruritic lesions that are discrete or coalescent, involving mucosal membranes and the upper layer of the dermis. It rises in minutes or hours and almost always resolves in 24 hours (1). Urticarial episodes that last less than 6 weeks are considered as acute urticaria and those lasting longer than 6 weeks as chronic urticaria. Furthermore, episodic acute intermittent urticaria/angiooedema lasts for hours or days, recurring over months or years $(2,3)$. Urticaria affects $15-25 \%$ of the population at least once in their lifetime. It is estimated that the prevalence of acute urticaria is 6-7\% in preschool children $(4,5)$. IgE-mediated reactions such as food allergy, drug allergy, insect bite reactions and systemic diseases are accused in the etiopathogenesis whereas viral upper airway infections are the most common factor triggering urticaria in childhood $(1,3)$. Chronic urticaria is seen in $0.1-3 \%$ of children (6). The most common causes of chronic urticaria are idiopathic and autoimmune (7). Physical factors such as cold and pressure are other etiologic factors in children (6). Furthermore, $4 \%$ of the patients have thyroid auto-antibody positivity regardless of whether they are euthyroid or not (2). A lesional skin biopsy is essential to confirm the diagnosis of vasculitic urticaria if urticarial plaques last more than 24 hours, are associated with petechia or purpura, are painful or burning, or have accompanying fever or arthralgia (2).

Angioedema is characterized by a similar process occurring in the deeper subcutaneous tissues. Angioedema occurs isolated in $10 \%$ of patients with urticaria and concomitantly in $50 \%$ while $40 \%$ have only urticaria (5).

Patients with urticaria make up a large proportion of the referrals to the allergy clinic. There are many causes of urticaria and its clinical history which is important when attempting to identify potential causes. Children develop urticaria commonly as a result of viral respiratory infections. Getting a detailed history of the patient is essential before evaluation. Since so many factors are involved in the etiology and assessment of the patients, investigating etiological factors is generally time consuming and expensive, making it more difficult to assess urticaria in childhood. This study was planned to evaluate the etiological aspects and the discrepancy of triggering factors of urticaria among children presenting at our outpatient clinic during a 1 -year period.

\section{METHODS}

In this retrospectively designed study, we reviewed the medical records of all children with a diagnosis code of urticaria that were seen in our allergy outpatient clinic between September $1^{\text {st }} 2008$ and August $31^{\text {st }} 2009$.
Demographic and historical information data shown below were recorded.

- Age and gender

- Characteristics, frequency and duration of symptoms

- Presence or absence of angioedema

- Predisposing factors or factors increasing the severity (food, drug, infection, insect bite, vaccine exposure in the last month)

- Triggering physical factors (cold, heat, pressure, aqua, solar exposure)

- Family and individual history of atopy

- History of other diseases

During investigation of acute urticaria, a complete blood count, peripheral blood smear, throat culture, posteroanterior chest radiography, stool examination, urine analyses, cold agglutinin and specific antibody for Mycoplasma pneumonia if atypical pneumoniawas considered, hepatitis Bvirus surfaceantigen, and anti-hepatitis $\mathrm{C}$ tests were performed. However, when chronic urticaria was suspected, abdominal ultrasonography, thyroid function tests and thyroid autoantibody (i.e. antithyroglobulin and antiperoksidase antibodies) tests, and urea breath test for Helicobacter pylori were performed in addition to the previously mentioned tests. Additionally, serum complement C3, C4 levels, antinuclear antibody, antids-DNA antibodies were investigated and skin biopsies were performed for patients who had clinical characteristics of vasculitic urticaria.

The skin prick test was performed on patients who had a history of food or drug allergy and suspected history of atopy.

The skin prick test (SPT): All patients and parents were informed about the course of SPT and gave signed consent prior to the beginning of the test. The patient's antihistaminic medication, if any, was stopped at least three days before the test. A drop of the allergen solution at standard activity and concentration was placed on the skin and let to seep into the epidermis with the help of a Stallerpoint. The allergens used included pollens, fungal spores, mites, animal fur and various food substances (Stallergenes S.A.-France). The skin reaction was evaluated 20 minutes later. The size of any wheal and flare reactions were compared with the size with negative (antigen diluting solution) and positive (histamine hydrochloride 10mg/ $\mathrm{ml}$ ) controls. An induration $>3 \mathrm{~mm}$ was accepted as positive. Additional foods or aeroallergens were tested on any patient based on parental concern.

Statistical Analysis: The SPSS version 10.0 (Chicago, IL, USA) software package program was used. Descriptive statistics were used for the distribution of patient demographic characteristics and disease-related characteristics, and diagnostic procedures. The definitions were provided as number and percentage for discrete variables and mean and standard deviation for continuous variables. 


\section{RESULTS}

A total of 3690 patients presented at our outpatient allergy clinic in one year and $7 \%$ of these patients had urticaria. A total number of 258 patients aged between 6 months and 17 years (mean $6.43 \pm 3.97$ ) were enrolled of whom 159 were male $(61.2 \%)$. A positive history of family atopy was found in $19(7.4 \%)$ of the subjects. All patients except seven were evaluated with laboratory tests. Seven patients had no obvious identified etiological factors. The clinical features of the patients are seen in Table I. Table II shows the characteristics of patients according to the type of urticaria.

Infections were the most common etiologic factor and were seen in 122 patients (47\%). Ten (3.9\%) of the patients had food allergy and six (2.3\%) had drug allergy. Among history of drug reactions, two had penicillin, two had cephalosporin, one had desferrioxamine and one had methylphenidate intake history. The skin prick test was performed on 107 subjects and 26 (24.3\%) of them had a positive SPT result to miscellaneous allergens. Among food allergies, positive skin prick test results were as follows: one to walnut, one to potato, one to strawberry, one to egg yolk and hazelnut, one to egg yolk and egg white, one to egg yolk, and three to egg yolk, egg white and milk allergen.

Two patients with chronic urticaria had thyroid autoantibody although they were euthyroid and endocrine follow-up was planned for these patients. Furthermore two patients with chronic urticaria had hepatosteatosis on abdominal ultrasound investigation. The ultimate explanation for this condition was their obesity problem.

Skin biopsies were performed for five patients with clinical characteristics of vasculitic urticaria. Among these, four had acute urticaria and one had episodic acute intermittent urticaria and three biopsy results were consistent with vasculitic changes. Two patients with urticarial vasculitis had Familial Mediterranean Fever (FMF) disease and 1 had Type 1 Diabetes Mellitus.

Table I: Clinical characteristics of patients with urticaria.

\begin{tabular}{|l|c|c|}
\hline & $\mathbf{n}$ & $\%$ \\
\hline Type of urticaria & 173 & 67 \\
\hline \multicolumn{1}{|c|}{ Acute } & 49 & 19 \\
\hline Episodic & 36 & 14 \\
\hline Chronic & 31 & 12 \\
\hline Association of angio-oedema & 6 & 2.3 \\
\hline Physical urticaria & 3 & 1.1 \\
\hline Cold & 3 & 1.1 \\
\hline Cholinergic & 3 & 1.1 \\
\hline
\end{tabular}

\section{DISCUSSION}

There are many etiological factors in urticaria. A detailed history and excellent physical examination are important for diagnosing the triggering factor. Consistent with the literature, we found acute urticaria to be more common than the chronic form in childhood (67\%). Nettis et al.(8) carried out their study on 562 consecutive patients (384 females) aged between 5 and 86 and reported a female predominance. On the contrary, in our study males were more commonly affected among all groups with 159 males $(61.2 \%)$ and the age range was six months to 17 years. We can say that urticaria is seen more commonly in males in childhood. Consistent with our findings, a study from Turkey reported male dominance in the adolescent period (9). Ferrer et al.(10) reported that middle-aged women are most commonly affected from chronic urticaria because autoimmune diseases are seen more frequently in women but there is no gender difference in children.

Acute urticaria is caused frequently by lgE-mediated allergic reactions to foods or by acute infections, usually viral respiratory tract infections. Papular urticaria occurs more often in children and is usually due to insect bites (6). Infections are accused as the most common cause of acute urticaria in childhood $(1,3,6)$. It is thought that complement activation due to immune complexes in infections causes the urticaria. Our study revealed that infections were the leading cause of acute urticaria as previously mentioned in literature (47\%). Sinusitis, dental infections, and urinary tract infections play a role in the etiology of acute urticaria but the most common cause is viral respiratory tract infections $(1,3,6)$. As previously reported by several studies, we found that upper airway infections were the most common etiological factor. In contrast, Sackesen et al.(9) found urinary tract infections to be the leading causative agent for acute urticaria. Only one of our patients had a urinary tract infection and he was in the chronic group. M. pneumonia may show various skin manifestations including urticaria. A study from Taiwan suggested that complete resolution of the urticaria occurred when acute urticaria patients with $M$. pneumonia who did not respond to antihistamine treatment received azithromycin (11). Consistent with the previous study, there were two patients with $M$. pneumonia in our acute urticaria study group and their urticaria recovered after treatment by clarithromycin.

IgE-dependent factors such as food allergy, drug allergy and insect bite reactions are other etiologic agents in acute urticaria. Idiopathic urticaria is a condition where no etiologic agent for urticaria is determined (4). We performed the skin prick test on patients with a history of food and drug allergy and found sensitization to food in 3\% and to drugs in 3\%. Reactions to some drugs such as penicillins and its derivatives cause IgEmediated reactions and lead to positive skin prick tests (6). In our study, four subjects had a history of receiving penicillin and cephalosporins and their skin prick tests were positive. On 
Table II: Characteristics of patients according to the urticaria type.

\begin{tabular}{|c|c|c|c|c|c|c|}
\hline & \multicolumn{2}{|c|}{ Acute } & \multicolumn{2}{|c|}{ Episodic } & \multicolumn{2}{|c|}{ Chronic } \\
\hline & $(n=173)$ & $\%$ & $(n=49)$ & $\%$ & $(n=36)$ & $\%$ \\
\hline \multicolumn{7}{|l|}{ Age } \\
\hline Min-max & \multicolumn{2}{|c|}{6 months- 17 years } & \multicolumn{2}{|c|}{$1-17$ years } & \multicolumn{2}{|c|}{$3-17$ years } \\
\hline Median (years) & \multicolumn{2}{|c|}{5} & \multicolumn{2}{|c|}{5} & \multicolumn{2}{|c|}{11.5} \\
\hline Mean (years) & \multicolumn{2}{|c|}{$5.49 \pm 3.61$} & \multicolumn{2}{|c|}{$7.03 \pm 3.58$} & \multicolumn{2}{|c|}{$10.15 \pm 3.88$} \\
\hline Male & 103 & 59.5 & 29 & 59.2 & 27 & 75 \\
\hline \multicolumn{7}{|l|}{ Aetiology } \\
\hline \multicolumn{7}{|l|}{ Infections } \\
\hline Upper airway infection & 92 & 53.1 & 5 & 10.2 & - & - \\
\hline Lower airway infection & 4 & 2.3 & - & - & - & - \\
\hline H. pylori & - & - & 4 & 8.1 & 9 & 25 \\
\hline Parasites & 4 & 2.3 & 1 & 2.0 & - & - \\
\hline M. pneumonia & 2 & 1.1 & - & - & - & - \\
\hline Urinary tract infection & - & - & - & - & 1 & 2.7 \\
\hline Papular urticaria & 22 & 12.7 & 5 & 10.2 & - & - \\
\hline Food allergy & 6 & 3 & 4 & 8.1 & - & - \\
\hline Drug allergy & 6 & 3 & - & - & - & - \\
\hline Auto-immune thyroiditis & - & - & - & - & 2 & 5.4 \\
\hline Hair dye & 1 & 0.6 & - & - & - & - \\
\hline Venom allergy & 1 & 0.6 & - & - & - & - \\
\hline Atopy (Aeroallergen) & 2 & 1.1 & 7 & 14.3 & 7 & 19.4 \\
\hline Idiopathic & 28 & 16.2 & 21 & 42.9 & 12 & 33.3 \\
\hline
\end{tabular}

the other hand, one patient was using desferrioxamine. The urticaria incidence ranges from $1 / 10$ to $1 / 100$ in patients taking desferrioxamine in the literature (12).

Skin biopsy is appropriate for diagnosing vasculitic urticaria in subjects who have lesions lasting more than 24 hours, lesions associated with pain or burning, fever, arthralgia and a high sedimentation rate, and recover with petechia or purpura (2). We have performed skin biopsy in 5 of our patients whose lesions were likely to be vasculitisc and 3 of them had pathologic findings compatible with a vasculitic process. Previous studies have shown that urticaria can be seen in auto inflammatory diseases. Two of the patients who had urticarial vasculitis were FMF patients. A study from Spain suggested that urticaria is the least cutaneous manifestation form seen in FMF patients (13). It is not surprising that coalescence of urticaria with FMF is more frequent than in other countries because of the high incidence of FMF in Turkey.

Data from the literature about the association between Type I diabetes and urticaria suggests a concomitance with auto- immune thyroid disease. Hyman et al. (14) reported a 12-year-old boy who was suffering from chronic urticaria and was diagnosed with autoimmune thyroid disease during routine evaluation who developed type 1 diabetes shortly after thyroid hormone replacement was initiated. In the present study, our patient had normal thyroid function tests and negative autoantibody but he will be followed up for potential development of autoimmune disorders.

Association of chronic urticaria with auto-immune diseases, especially with thyroid disorders has been frequently reported. The prevalence in adults ranges from $14 \%$ to $33 \%$. Lewy et al. (15) reported the prevalence of thyroid autoimmunity as $4.3 \%$ in their pediatric population. Consistent with our study, Cebeci et al. (16) reported that 31 of 41 patients with chronic urticaria had euthyroid status. Therefore we can claim that auto-antibody for thyroid should be screened especially in adolescents with chronic urticaria even when thyroid function test results are in the normal range. 
Chemicals in hair dye such as nickel, thioglycolate, p-phenylendiamine, persulphates, quaternary ammonium compounds, protein hydrolysates, surfactants, latex, rubber haptens and others may induce allergic cutaneous diseases (17). One of our patients with acute urticaria had a history of using hair dye, so we especially think that hair dye use should be asked for in adolescent female patients with acute urticaria

Data from the literature suggests infections and physical factors are common etiological agents for chronic urticaria in the pediatric population. We found the infections and idiopathic factors were more common in our patients. It is suggested that gastrointestinal infections with $\mathrm{H}$. pylori, bacterial infections of the nasopharynx (recurrent sinusitis and tonsillitis) and infections of the roots of the teeth can cause urticaria. H. pylori plays a role in chronic urticaria by developing functional auto-antibody against IgE receptor (18). In our study, H. pylori was identified in four patients with acute urticaria and nine patients with chronic urticaria. On the other hand, there are studies suggesting no relationship between urticaria and $H$. pylori and its treatment (19). In the present study, we found $H$. pylori to be the causative agent in $25 \%$ of chronic urticaria patients and their urticaria resolved after eradication.

Only six patient had parasites in our study. There are contradictory studies about the role of parasites in urticaria in the literature (20). It is a rare causative agent in some countries such as North European countries but concomitance between parasites and urticaria increases as its prevalence increases in a country, as in Turkey.

In conclusion, urticaria has a versatile etiology and infections are the most common etiologic factor both in acute and chronic urticaria. History and physical examination are the best tools for diagnosis. The necessary tests should be done only when suggested by history and physical examination and subjects with acute urticaria should only be observed with no additional tests.

\section{REFERENCES}

1. Kaplan AP. Urticaria and angio-oedema. In: Middleton E, Reed CE, Ellis EF, Adkinson NF, Yunginger JW, Busse WW, editors. Allergy: Principles and Practice Seventh ed. St. Louis:Mosby, 2008; 1063-81.

2. Powell RJ, Du Toit GL, Siddique N, Leech SC, Dixon TA, Clark AT, et al. BSACl guidelines for the management of chronic urticaria and angio-oedema. Clin Exp Allergy 2007;37:631-50.
3. Zuberbier T, Asero R, Bindslev-Jensen C, Canonica GW, Church MK, Gime'nez-Arnau AM, et al. EAACI/GA2LEN/EDF/WAO guideline: Definition, classification and diagnosis of urticaria. Allergy 2009;64:1417-26.

4. Khan DA. Chronic urticaria: Diagnosis and management. Allergy Asthma Proc 2008; 29:439-46.

5. Ferdman RM. Urticaria and angioedema. Clin Ped Emerg Med 2007;8:72-80.

6. Deacock SJ. An approach to the patient with urticaria. Clin Exp Immunol 2008;153:151-61.

7. Bailey E, Shaker M. An update on childhood urticaria and angioedema. Curr Opin Pediatr 2008;20:425-30.

8. Nettis E, Pannofino A, Aprile CD, Ferranini A, Tursi A. Clinical and aetiological aspects in urticaria and angio-oedema. Br J Dermatol 2003;148:501-6.

9. Sackesen C, Sekerel BE, Orhan F, Kocabas CN, Tuncer A, Adalioglu $\mathrm{G}$. The etiology of different forms of urticaria in childhood. Pediatr Dermatol 2004;21:102-8.

10. M Ferrer. Epidemiology, healthcare, resources, use and clinical features of different types of urticaria Alergologica. J Investig Allergol Clin Immunol 2009;19 Suppl 2: 21-6.

11. Wu CC, Kuo HC, Yu HR, Wang L, Yang KD. Association of acute urticaria with Mycoplasma pneumoniae infection in hospitalized children. Ann Allergy Asthma Immunol 2009;103:134-9.

12. McLeod C, Fleeman N, Kirkham J, Bagust A, Boland A, Chu P, et al. Deferasirox for the treatment of iron overload associated with regular blood transfusions (transfusional haemosiderosis) in patients suffering with chronic anaemia: a systematic review and economic evaluation. Health Technol Assess 2009;13:1-121.

13. Alonso R, Cisteró-Bahima A, Enrique E, San Miguel-Moncín MM. Recurrent urticaria as a rare manifestation of familial Mediterranean fever. J Investig Allergol Clin Immunol 2002;12:60-1.

14. Hyman SJ, Shreffler WG, Rapaport R. Type 1 diabetes, autoimmune thyroid disease, and chronic urticaria. Pediatr Diabetes 2008;9: 508-11.

15. Levy Y, Segal N, Weintrob N, Danon YL. Chronic urticaria: Association with thyroid autoimmunity. Arch Dis Child 2003;88: 517-9.

16. Cebeci F, Tanrikut A, Topcu E, Onsun N, Kurtulmus N, Uras AR. Association between chronic urticaria and thyroid autoimmunity. Eur J Dermatol 2006;16:402-5.

17. Ferrari M, Moscato G, Imbriani M. Allergic cutaneous diseases in hairdressers. Med Lav 2005;96:102-18.

18. Hernando-Harder AC, Booken N, Goerdt S, Singer MV, Harder $\mathrm{H}$. Helicobacter pylori infection and dermatologic diseases. Eur J Dermatol 2009;19:431-44.

19. Hellmig S, Troch K, Ott SJ, Schwarz T, Fölsch UR. Role of Helicobacter pylori infection in the treatment and outcome of chronic urticaria. Helicobacter 2008;13:341-5.

20. Jirapongsananuruk O, Pongpreuksa S, Sangacharoenkit P, Visitsunthorn N, Vichyanond P. Identification of the etiologies of chronic urticaria in children: A prospective study of 94 patients. Pediatr Allergy Immunol 2010:21:508-14. 